\title{
РЕЦЕНЗИИ
}

\section{REVIEW OF THE BOOK: Ch.J. HALPERIN. IVAN THE TERRIBLE: FREE TO REWARD AND FREE TO PUNISH}

\author{
M. Salomon Arel \\ Marianopolis College \\ Westmount, Quebec, Canada \\ m.salomon@marianopolis.edu
}

\begin{abstract}
In Ivan the Terrible: Free to Reward and Free to Punish, Charles Halperin brings together his many years of research, study, and reflection on Ivan IV, a ruler who presided over important and lasting reforms in Russia in the mid-sixteenth century and led the conquest of the Volga khanates of Kazan and Astrakhan. Ivan is known for much more, however, as his reign also involved large-scale, often savage attacks on his own subjects, carried out through the mechanism of the variously defined and understood oprichnina. Historians have been prolific in their work on this most (in)famous of Russian tsars. This book is an important addition to the voluminous and still growing historiography on Ivan. As much a study of Muscovite society, economy, politics, and culture in Ivan's time as of the tsar himself, it situates him firmly in the Muscovy that had evolved in the century leading to his accession to the throne, a century of expansion and profound change affecting all segments and aspects of society. For Halperin, the attendant and deepening social tensions and malaise provide the context for understanding Ivan as a complex ruler and human being who was challenged by his times and responsibilities. They also, as Halperin persuasively argues, help explain the complicity of so many Muscovites alongside the ruler in the unleashing of "mass terror", which, in this book, is seen not as the product of Ivan's sick mind or thirst for unlimited power, but as an expression of "social pathology" run rampant, beyond the intentions of a tsar whose actions prepared the soil for such violence.
\end{abstract}

Keywords: Ivan IV, Ivan the Terrible, Muscovy, oprichnina, autocracy

For citation: Salomon Arel M. Review of the Book: Ch.J. Halperin. Ivan the Terrible: Free to Reward and Free to Punish. Zolotoordynskoe obozrenie=Golden Horde Review. 2020, vol. 8, no. 2, pp. 386-390. DOI: 10.22378/2313-6197.2020-8-2.386-390

Charles Halperin on Ivan the Terrible addresses his infamous subject with a precision, erudition, clarity, and understanding that should come as no surprise to anyone in the field of Muscovite history. Halperin has been deeply immersed in the study of all things 'Ivan' for years, sharing his findings and thoughts along the way in a number of probing articles. His illuminating monograph [1] on the most studied, yet, still, frustratingly enigmatic of Russian rulers lives up to expectations, challenging us to think again, and more comparatively about both Ivan and the environment, domestic and international, in which he reigned and ruled, prayed and 
terrorized. The Ivan Halperin places before us through an exhaustive consideration of a voluminous and still growing historiography (Russian, Soviet, Western) and a robust, almost forensic assessment of the sources, is as tyrannical and terrifying as ever, but somewhat less elusive.

In this telling, Ivan is humanized more than we have seen in other studies, or at least in a more rounded and contextualized fashion. As Halperin shows in analyzing documented episodes of Ivan's life and reign, cautiously informed by sources whose limitations, inaccuracies, or biases he discerns with skill and basic common sense, there is no "good" tsar here, followed by "bad" tsar, but rather a ruler "all too human", who was "good and bad, not all good or all bad, or good in one period and bad in another". In other words, Ivan was "flawed" and "contradictory", like most people and like other rulers, including contemporaries, to whom this book often alludes. He was also an "inveterate liar who manipulated history, including his own" to serve his purposes, including in his correspondence with Kurbskii, which, significantly, Halperin accepts as authentic, although "mendacious", useful for revealing "point of view or at least propaganda, but not always reliable in . . . factual content".

No assessment of Ivan or his reign can ignore origins, or how this tsar was the product of a childhood and adolescence conditioned by a fraught court environment during a period of tumultuous regency (as regencies, one should note, are apt to be). In Halperin's estimation, this world did not pose an actual "threat" to Ivan's life or position, at least not as far as the historical record shows and, thus, was not likely to have marked him psychologically, at least not excessively. The case is persuasively made, yet one might counter that the perception of threat is what is, ultimately, most important and that young, orphaned Ivan's subjective perception might have been acute even where actual threat was objectively minimal. And, while it is true, as Halperin helpfully reminds us, that other rulers of the time, Elizabeth I, for example, endured worse in their youth with no signs of trauma in later life, it is a tricky business to compare how different individuals respond to similar circumstances, especially taking into consideration a multiplicity of factors sure to influence response, including temperament, gender, family relations and support, and political culture.

Moving forward into the oprichnina era, Halperin, in fact, relates how Ivan's sense of threat appears to have been disturbingly heightened, as he became "so suspicious, if not paranoid, that he could not tell the difference between actual and fictitious foes". The latter point raises the issue of whether the tsar suffered from some form of mental illness, extreme anxiety or paranoia, for example, as many have argued. Halperin is not among them, though, rejecting the notion that Ivan was insane or psychologically impaired. The oprichnina, whose meaning (literally and substantively) has confounded generations of historians, is not presented here as an instrument of repression conceived in derangement stemming from childhood trauma or personality disorder, but, rather, as an asylum, so to speak, for a ruler seeking some "respite from the throne", or more precisely, from "politics". Building on Cherniavsky's discussion of Muscovite political ideology and the three "myths" (images) of the ruler, Halperin argues that the creation of the oprichnina was an effort by Ivan to achieve not "unlimited power", but rather "symbolic and physical autonomy from his role as ruler", which had become, at least for a time, too onerous. The tsar sought to become not an autocrat, but to "escape his ideologi- 
cal burden, the obligation to commit un-Christian acts in order to rule effectively". His goal was, thus, neither irrational, nor political, but, rather, personal and ideologically-grounded.

One might reasonably counter that such a goal points us back to possible mental illness, as a "stable" or "sane" ruler would not have felt the weight and contradiction of his divinely-ordained tasks so acutely as to take the drastic and perplexing action that he did. The larger part of Halperin's argument, however, suggests that Ivan was operating in an exceptionally challenging context, which, if we accept to be the case, lends support to his understanding of the oprichnina's origins. As Halperin sees it, what is most significant about the sixteenth century context he carefully lays out for his readers is that it was characterized at all levels and across all domains by change - and by extension, social tension and instability. To be more precise, by the time Ivan was old enough to wield his sceptre, Muscovy had experienced a century of significant and unrelenting change centred on "social mobilization and social engineering". The goal was to arm the government with the resources and manpower needed to support Muscovite expansion, a thrust which Ivan energetically embraced, first with the conquest of Kazan and Astrakhan, an ultimately defensive imperative in Halperin's view, followed by the truly aggressive, albeit unsuccessful offensive against Livonia. As society-wide change continued to progress, Halperin reminds us, "boyars became gentry; gentry became boyars, bureaucrats, or slaves; bureaucrats became gentry; merchants became bureaucrats; [and] peasants became slaves, priests, bureaucrats, musketeers, or Cossacks".

These transformations have not gone unnoticed, of course, in the larger literature on Muscovy. However, what Halperin has done that is both new and important, even startling, is to bring them all together and underscore what it meant for Muscovites across all social strata to witness and/or experience social change of such breadth and intensity that it exceeded the limits of what a "traditional society" - by definition, wary of if not outright hostile to social mobility - could safely "tolerate". Thus, although, Muscovy in the $1530 \mathrm{~s}-50 \mathrm{~s}$ showed undeniable signs of economic prosperity and appeared to be an "optimistic, self-assured state and society", under the surface, social strain was stretched as taut as the system could endure, the demands of the Livonian War further exacerbating deep and widespread social malaise. That tension, it would appear from Halperin's exposition of the "big picture", underlay Ivan's withdrawal into the oprichnina, his own malaise in the face of a very real simmering cauldron of social discontent pushing him away from his traditional role at a moment in Muscovite history when traditional society was struggling to absorb the new.

Which brings us to the horrors of the oprichnina. While there can be no doubt that monstrous acts were committed and thousands of innocent victims perished, as this book soberly outlines, it also rightly underscores that so many sources detailing Ivan's alleged villainy and delusional, sadistic behaviour were the "dubious" products of "sensationalist anti-Muscovite propaganda" written by foreigners during the Livonian War. Moreover, it bears reminding, as Halperin notes, that Ivan's contemporaries were no saints, when it came to deadly repression and violence against rebels, dissenters, and other foes who threatened state, social, or religious order. What makes Ivan appear worse, Halperin proposes, is not just the lurid propaganda, but that his agenda is much less clear than that of others wielding power in 
his day (be they Henry VIII or Philip II), as are the threats he claimed to be combatting. One cannot but agree with Halperin's observation that gratuitous violence, or what appears as such, is much more difficult to process or justify, hence its perpetrator more easily vilified. All that being said, it is beyond dispute that, with the oprichnina, Ivan unleashed what Halperin calls "mass terror" on his subjects behaviour unlike that of any other Russian ruler before or after him in the preSoviet era.

What some might take issue with in his discussion here is Halperin's further point that mass terror was "certainly not what Ivan intended", when he sought to "escape his moral dilemma as ruler" in challenging times. Unlike Perrie and Pavlov most recently (2003), who opt to "deduce intentions from outcomes", Halperin explicitly chooses not to, allowing for the possibility that outcomes sometimes proceed from forces other than intent. His argument here is that the mass terror inflicted by the oprichnina as it progressed could not have happened without the support and participation of thousands of Muscovite elites: the gentry, who dominated the oprichniki corps and expressed their "angst, frustration, resentment, or social animosity" in "the most dysfunctional way imaginable, with unmitigated violence", and others outside the oprichnina, who seized the opportunity "to advance their careers by joining the orgy of denunciations accompanying [the] atrocities". In other words, mass terror was a society-wide phenomenon, not only in terms of its victims, but, more importantly, in terms of it perpetrators. From this persuasively argued perspective, explanations that focus solely on Ivan, his state of mind, or his supposed pursuit of unlimited power fail to credit the agency of disgruntled Muscovites to act in their perceived interests, as destructive as these might have been.

In this scenario, tsar and elites were complicit in the "social pathology" that played out to devastating effect across the country and society. In the end, though, as Halperin soberly assesses, Ivan bears ultimate responsibility, even if his operatives savagely attacked his subjects "in violation of [his] wishes". To this reader, what these wishes truly were remains somewhat of a question mark. However, the underlying forces in Muscovite society that made the oprichnina possible, regardless of Ivan's intent, have been laid bare. Future historians of Ivan and his reign still have much to investigate and explain. Halperin has given them plenty to think about.

\section{REFERENCES}

1. Halperin Ch.J. Ivan the Terrible: Free to Reward and Free to Punish. Pittsburgh: University of Pittsburgh Press, 2019. 378 p.

About the author: Maria Salomon Arel - Professor of History, Department of History, Marianopolis College (4873 Westmount Ave., Westmount, Quebec, H3Y 1X9, Canada). E-mail: m.salomon@marianopolis.edu 


\title{
РЕЦЕНЗИЯ НА КНИГУ: Ч. ГАЛЬПЕРИН. ИВАН ГРОЗНЫЙ: ВОЛЬНЫЙ НАГРАЖДАТЬ ИЛИ НАКАЗЫВАТЬ
}

\author{
М. Саломон Арел \\ Марианополис Колледж \\ Уэстмаунт, Квебек, Канада \\ m.salomon@marianopolis.edu
}

В своей книге «Иван Грозный: Вольный награждать или наказывать» (Ivan the Terrible: Free to Reward and Free to Punish. Pittsburgh: University of Pittsburgh Press, 2019) Чарльз Гальперин объединяет свои многолетние исследования и размышления об Иване IV, правителе, который ввел в действие важные реформы в России середины XVI века, оказавшие влияние и на последующие периоды, и кто возглавил завоевание Поволжских ханств Казани и Астрахани. Иван IV, однако, более известен тем, что в его правление имели место крупномасштабные и часто бежалостные нападения на его же собственных подданных, осуществляемые в рамках механизма по-разному определяемой и понимающейся опричнины. Историки оказались продуктивны в исследованиях этого знаменитого (и одновременно бесславного) русского царя. Настоящая книга в свою очередь является важным дополнением к обширной и постоянно растущей историографии об Иване. Будучи не только исследованием московского общества, экономики, политики и культуры во времена Ивана, но и самого царя, данная книга представляет личность царя в контексте той Московии, которая эволюционировала на протяжении столетия, в котором имело место его восшествие на престол - столетия экспансии и глубинных изменений, затронувших все сегменты и аспекты общества. Для Гальперина сопутствующая и усугубляющаяся социальная напряженность являются тем контекстом, который помогает понять Ивана в качестве сложного правителя и человека, оказавшегося под давлением вызовов своего времени и обязанностей. Как убедительно утверждает Гальперин, эти вызовы помогают объяснить соучастие многих москвичей в развязывании их правителем «массового террора», который в этой книге не рассматривается как продукт безумия Ивана или жажды неограниченной власти, но как выражение «социальной патологии», вышедшей из под контроля царя уже после того, как он подготовил своими действиями почву для такого насилия.

Ключевые слова: Иван IV, Иван Грозный, Московия, опричнина, самодержавие

Для цитирования: Salomon Arel M. Review of the Book: Ch.J. Halperin. Ivan the Terrible: Free to Reward and Free to Punish // Золотоордынское обозрение. 2020. T. 8, № 2. C. 386-390. DOI: 10.22378/2313-6197.2020-8-2.386-390

Сведения об авторе: Мариа Саломон Арел - профессор департамента истории, Марианополис Колледж (4873 Westmount Ave., Westmount, Quebec, H3Y 1X9, Canada). E-mail: m.salomon@marianopolis.edu 